*Mestre em Proteção dos Direitos Fundamentais pela Universidade de Itaúna (UIT) e Graduado em Direito pela Faculdade de Direito de Conselheiro Lafaiete (FDCL).E-mail: andre@ gonzagaesantana.adv.br

**Pós-Doutor em Direito junto a Università degli Studi di Messina, Itália. Doutorado em Direito pela UGF - RJ. Professor da Graduação e do PPGD - Mestrado em Direito Proteção dos Direitos Fundamentais e Graduação da Universidade de Itauna (UIT) e das Faculdades Santo Agostinho (FASASETE).

E-mail: deilton.ribeiro@terra. com.br

\section{A Fundamentação da Decisão e as Garantias \\ Do Contraditório No Julgamento Do Recurso EXTRAORDINÁRIO REPRESENTATIVO DA CONTROVÉRSIA \\ $N^{\circ} 566.622$}

THE REASONING BEHIND THE DECISION AND THE GUARANTEES OF THE ADVERSARY PROCESS IN THE JUDGMENT OF THE EXTRAORDINARY APPEAL REPRESENTATIVE OF CONTROVERSY $\mathrm{N}^{\circ} 566.622$

\section{André dos Santos Gonzaga* Deilton Ribeiro Brasil***}

Como citar: GONZAGA, André dos Santos; BRASIL, Deilton Ribeiro. A fundamentação da decisão e as garantias do contraditório no julgamento do Recurso Extraordinário representativo da controvérsia $n^{\circ} 566.622$. Revista do Direito Público, Londrina, v. 16, n. 1, p. 171-185, abr. 2021. DOI: 10.5433/24157-108104-1.2021v16n1p. 171. ISSN: 1980-511X

Resumo: A presente pesquisa tem como centro a fundamentação da decisão e as garantias do contraditório no julgamento do Recurso Extraordinário Representativo da Controvérsia n 5 566.622, pelo Supremo Tribunal Federal. A metodologia adotada foi a revisão bibliográfica, baseada em fontes primárias e secundárias, sendo utilizado o método indutivo. A pesquisa foi desenvolvida com a realização da análise do Recurso Extraordinário Representativo da Controvérsia $\mathrm{n}^{\mathrm{o}}$ 566.622, sobre o voto do relator Ministro Marco Aurélio. Para alcançar os objetivos propostos foi realizado um estudo sobre o processo constitucional e jurisdição no Estado Democrático de Direito, bem como a participação do amicus curiae no julgamento do recurso extraordinário representativo da controvérsia $\mathrm{n}^{\circ} 566.622$.

Palavras-chave: Garantia do contraditório. Fundamentação das decisões. Participação das partes. Amicus Curiae. Recurso extraordinário representativo da controvérsia n566.622.

Abstract: This research focuses on the rationale of the decision and guarantees of the adversarial process in the judgment of the Extraordinary Appeal Representative of Controversy No. 566.622, by the Federal Supreme Court. The methodology utilized was bibliographical review, based on primary and 
secondary sources, using the inductive method. This research was developed with an analysis of the Extraordinary Appeal Representative of Controversy No. 566.622, specifically Justice Marco Aurélio decision. To achieve this study's objective, it explored the constitutional process and jurisdiction in a Democratic State of Law, as well as the participation of amicus curiae in the trial of Extraordinary Appeal Representative of Controversy No. 566.622 .

Keywords: Contradictory Warranty. Rationale of Decisions; Participation of the Subjects. Amicus Curiae. Extraordinary Appeal Representing Controversy n ${ }^{\circ} 566.622$. 


\section{INTRODUÇÃO}

O presente artigo pretende analisar a fundamentação da decisão e as garantias do contraditório no julgamento do Recurso Extraordinário Representativo da Controvérsia n ${ }^{\circ} 566.622$, pelo Supremo Tribunal Federal.

A instrumentalidade técnica do processo requer mais do que a garantia de participação das partes. Requer que essa participação se dê em contraditório, com igualdade de oportunidades e que dela resulte essa consequência cujo alcance necessita ser apreendido em toda sua extensão que é a participação dos destinatários das sentenças em sua própria formação (GONÇALVES, 1992, p. 174).

É com esse enfoque que o artigo pretende analisar o julgamento do Recurso Extraordinário Representativo da Controvérsia $n^{\circ} 566.622$, mais precisamente o voto do relator Ministro Marco Aurélio.

Dessa forma, será realizado um estudo sobre o processo constitucional e jurisdição no Estado Democrático de Direito, bem como a participação do amicuscuriae no julgamento do recurso extraordinário representativo da controvérsia $\mathrm{n}^{\circ} 566.622$.

Também será verificado se o acordão proferido pelo Supremo Tribunal Federal no julgamento do Recurso analisado pode ser considerado como uma decisão participativa, onde as partes propriamente ditas e os intervenientes (amicus curiae) contribuíram para a construção do provimento jurisdicional final.

O procedimento metodológico de pesquisa adotada para a consecução dos objetivos propostos é a análise bibliográfica, que abrange a bibliografia disponibilizada em relação ao tema de estudo, desde publicações avulsas, boletins, revistas, livros, pesquisas, artigos, dissertações, teses, entre outros.

O método adotado é o indutivo, que pode ser definido por Marconi e Lakatos (2003) como o processo mental por intermédio do qual, partindo de dados particulares, suficientemente constatados, infere-se uma verdade geral ou universal, não contida nas partes examinadas. Portanto, o objetivo dos argumentos indutivos é levar a conclusões cujo conteúdo é muito mais amplo do que o das premissas nas quais se basearam.

O levantamento bibliográfico forneceu as bases teóricas e doutrinárias a partir de livros e textos de autores de referência, tanto nacionais como estrangeiros. Enquanto o enquadramento bibliográfico utiliza-se da fundamentação dos autores sobre um assunto, o documental articula materiais que não receberam ainda um devido tratamento analítico. A fonte primeira da pesquisa é a bibliográfica que instruiu a análise da legislação constitucional e a infraconstitucional, bem como a doutrina que informa os conceitos de ordem dogmática.

\section{BREVES CONSIDERAÇÕES SOBRE O RECURSO EXTRAORDINÁRIO REPRESENTATIVO DA CONTROVÉRSIA No 566.622}

O Recurso Extraordinário Representativo da Controvérsia de $\mathrm{n}^{\mathrm{o}} 566.622$, teve origem 
em uma ação ordinária anulatória de débito fiscal movida pela Sociedade Beneficente de Parobé, mantenedora do Hospital São Francisco de Assis, em face do Instituto Nacional do Seguro Social, objetivando ver afastada a cobrança de contribuições sociais, sob a alegação de ser titular da imunidade tributária prevista no artigo 195, § 7º da Constituição Federal de 1988.

O direito pleiteado foi reconhecido em $1^{\mathrm{a}}$ instância, sob o fundamento de que a Sociedade Beneficente de Parobé preenchia os requisitos versados no artigo 14 do Código Tributário Nacional, reconhecendo a inconstitucionalidade incidental do artigo 55 da Lei $\mathrm{n}^{\circ} 8.212 / 91$, haja vista ter invadido matéria reservada a lei complementar, segundo o artigo 146, inciso II, da Constituição Federal de 1988 (BRASIL, 1988, 1991).

No prosseguimento natural do processo, a sentença a quo foi reformada pelo Tribunal Regional Federal da $4^{\mathrm{a}}$ Região, que se baseou na ausência de imunidade considerando legítimas as exigências contidas no artigo 55 da Lei $n^{\circ} 8.212 / 91$ por se tratar de requisitos objetivos à caracterização da instituição como beneficente e filantrópica. A reforma da sentença teve, ainda, como fundamento o precedente do Supremo Tribunal Federal na Medida Cautelar requerida na Ação Direta de Inconstitucionalidade $\mathrm{n}^{\circ}$ 2.028/DF cujo relator foi o Ministro Moreira Alves, julgada em 11/11/99, que afastava a necessidade de lei complementar para dispor sobre as condições essenciais para alcançar a imunidade desejada. Por fim, considerou que o artigo $195 \S 7^{\circ}$ da Constituição Federal faz remissão genérica a lei, sem referência expressa à norma complementar, razão pela qual a regulação da matéria poderia ser realizada por meio de lei ordinária.

Insatisfeita com o acordão proferido pelo TRF da $4^{\mathrm{a}}$ Região, a Sociedade Beneficente de Parobé interpôs o recurso extraordinário (566.622/RS), arguindo em preliminar a repercussão geral da matéria. No mérito alegou que o acordão transgrediu os artigos 146 , inciso II e $195, \S 7^{\circ}$ da Constituição Federal de 1988, requerendo a inconstitucionalidade do artigo 55 da Lei no 8.212/91. Afirmou que o $\S 7^{\circ}$ do artigo 195 da Constituição Federal estabelece verdadeira imunidade tributária e que os requisitos para usufruir desse direito devem ser previstos por lei complementar nos termos do artigo 146, inciso II, que requer norma da espécie para regular as limitações constitucionais ao poder de tributar. Conclui que frente ao princípio da recepção, o Código Tributário Nacional, mais precisamente em seu artigo 14, seria o diploma complementar específico a disciplinar a matéria de imunidade tributária.

No exercício do contraditório, a Fazenda Nacional contesta a aplicação do Código Tributário Nacional como instrumento apto para dispor sobre os requisitos da imunidade prevista no artigo $195 \S 7^{\circ}$ da Constituição Federal, afirmando que o diploma legal aplicado ao caso seria a Lei $n^{\circ} 8.212 / 91$.

No julgamento do recurso extraordinário n $n^{\circ} 566.622 / \mathrm{RS}$ o plenário virtual do STF acolheu a preliminar de repercussão geral da matéria. Na instrução do recurso extraordinário supracitado, foi considerada a opinião do Ministério Público, sendo admitida a intervenção da Confederação Nacional dos Estabelecimentos de Ensino - CONFENEN e do Conselho Federal da Ordem dos Advogados do Brasil como amicus curiae. 


\subsection{Voto do relator Ministro Marco Aurélio}

Inicialmente o Relator apresentou a matéria a ser tratada informando que se tratava do recurso extraordinário $\mathrm{n}^{\mathrm{o}} 566.622$ que tinha por finalidade definir se os requisitos legais necessários para as entidades beneficentes de assistência social exercem a imunidade relativa às contribuições de seguridade social poderiam ser previstos em lei ordinária ou exclusivamente em lei complementar. Que a análise dos artigos 146, inciso II, e 195, $\S 7^{\circ}$, da Constituição Federal pelo Supremo Tribunal Federal, implicariano reconhecimento da inconstitucionalidade formal ou não do artigo 55 da Lei ${ }^{\circ} 8.212$, de 1991.

Informou que o Supremo Tribunal Federal já havia discutido matéria semelhante, porém sem uma definição, citando a Medida Cautelar na Ação Direta de Inconstitucionalidade $n^{\circ} 1.802 /$ DF, na Ação Direta de Inconstitucionalidade nº 2.028/DF e no Recurso Extraordinário n ${ }^{\circ}$ 636.941/ RS.

Como frisou o Relator, caberia ao Supremo elucidar a questão, julgando de forma definitiva a delimitação da competência regulatória concernente à regra do $\S 7^{\circ}$ do artigo 195 da Constituição Federal de 1988. Nesse diapasão, ponderou que era necessária a compreensão do papel político e social cumprido por esse instituto jurídico, uma vez que era indispensável para o trabalho do hermeneuta:

As normas de imunidade tributária constantes da Carta visam proteger valores políticos, morais, culturais e sociais essenciais, não permitindo que os entes tributem certas pessoas, bens, serviços ou situações ligadas a esses valores. Onde há regra constitucional de imunidade, não poderá haver exercício da competência tributária e isso ante uma seleção de motivos fundamentais (BRASIL, 2017).

Confirmando o posicionamento do Relator Ministro Marco Aurélio, José Souto Maior Borges (2011, p. 221), afirma que as imunidades servem para assegurar certos princípios fundamentais ao regime, a incolumidade de valores éticos e culturais consagrados pelo ordenamento constitucional positivo e que se pretende manter livres das interferências ou perturbações da tributação.

No mesmo sentido, Humberto Ávila (2012, p. 273) pondera que "a causa justificativa da imunidade é facilitar, por meio da exclusão de encargos tributários, a consecução de finalidades que devem ser atingidas pelo próprio Estado.”

Ainda, com entendimento semelhante, Aires Fernandino Barreto (2001), ensina que o constituinte ao prevê as imunidades tributárias no artigo 150 da Constituição Federal, buscou garantir a eficácia jurídica dos princípios constitucionais que consagram a proteção a valores éticos e culturais consagrados pelo ordenamento constitucional:

[...] o exame das situações descritas pelo constituinte, no artigo 150 da Constituição Federal, como imunes à tributação por via de impostos, revela que essas situações representam valores privilegiados, protegidos, consagrados 
pela ordem constitucional e, de conseguinte, impõe a conclusão no sentido de que essas imunidades constituem uma forma de assegurar, de garantir a eficácia jurídica dos princípios constitucionais que consagram a proteção a tais valores (BARRETO, 2001, p. 34).

Retornando ao voto do Relator, ponderou que os precedentes do Supremo, no tocante às imunidades das alíneas "a", "b", "c" e "d" do aludido inciso VI, do artigo 150 da Constituição Federal de 1988, vinha deixando clara a atenção do Supremo Tribunal Federal com as funções políticas e sociais dessas normas, utilizando-se da interpretação teleológica para a solução das controvérsias surgidas e buscando sempre a melhor realização dos valores protegidos.

Lembrou que em outro julgamento ( $R E n^{\circ} 237.718$, julgado em 29/03/2001), o então relator Ministro Sepúlveda Pertence, versou em seu voto que a jurisprudência do Tribunal vem sendo decisivamente inclinada à interpretação teleológica das normas de imunidade tributária, de modo a maximizar-lhes o potencial de efetividade, como garantia ou estímulo à concretização dos valores constitucionais que inspiram limitações ao poder de tributar (BRASIL, 2001)

Nesse passo, como ponderam Cláudio Pereira de Souza Neto e Daniel Sarmento (2012, p. 415-416), cada norma jurídica deve ser interpretada com consideração de todas as demais, e não de forma isolada, presente a buscar a harmonia e integridade sistêmica da Constituição Federal. Combinados os elementos sistemático e teleológico, a interpretação deve pautar nos princípios da dignidade da pessoa humana, da igualdade, do Estado Democrático de Direito, da República e da Federação.

O relator versou que o Supremo Tribunal Federal, na mencionada Medida Cautelar na Ação Direta de Inconstitucionalidade $n^{\circ} 2.028 / \mathrm{DF}$, já havia se posicionado em relação ao equivoco trazido no $\S 7^{\circ}$ do artigo 195 da Constituição Federal que versava sobre as isenções de contribuição à seguridade social as entidades beneficentes de assistência social, ou seja, que não se trata de isenção, mas de imunidade, limitando ao Estado o poder de tributar.

Nesse passo, discorreu sobre os dois requisitos garantidores da imunidade (ser pessoa jurídica que desempenhe atividades beneficentes de assistência social e atender a parâmetros legais), conceituando os requisitos e informando que o Tribunal interpreta o termo assistência social constante do artigo 203 da Constituição Federal de 1988 de forma mais ampla, abrangendo os serviços de saúde e educação. Por esse motivo, seguindo o Relator, o constituinte originário assegurou imunidade a essas atividades, tendo em vista que são atividades típicas do Estado em favor da realização de direitos fundamentais.

Em última análise ao primeiro requisito garantidor de imunidade, o relator versou que a fonte de legitimação e diretriz interpretativa dessa regra constitucional de imunidade perfaz o amparo à população mais carente. Ou seja, que toda pessoa jurídica que prestasse esses serviços, sem fins lucrativos, com caráter assistencial, em favor da coletividade, em especial dos hipossuficientes, estaria atuando em parceria com o Poder Público na satisfação de direitos fundamentais sociais. Esta é também a opinião de James Marins (1999): 
A Constituição Federal de 1998 juridiciza, garante e protege certos valores éticos que revelam a concepção democrática de vida e de governo. Por vezes o faz de modo a prestigiar certas atividades por meio de proteção concedida em face da ação tributária do Estado, limitando explicitamente seu campo impositivo (artigos 150, VI, alínea "a" e 195, § $7^{\circ}$ da Constituição Federal de 1988). Assim se dá com as atividades de educação e assistência social, não apenas por se prestarem a fins de reconhecida utilidade para a sociedade, mas também por seu papel de coadjuvante nos deveres do próprio Estado (artigos $6^{\circ}, 203$, combinados com os artigos 150, VI, alínea "c", e 195, § $7^{\circ}$, da Constituição Federal de 1988) (MARINS, 1999, p. 150).

Nesse sentido, Kioshi Harada (2005) narra que a primeira condição é decorrente da própria razão da imunidade. Assim como se dá com a alínea "c" do inciso VI do artigo 150, em relação à qual é ontológica e finalisticamente vinculada, a norma do $\S 7^{\circ}$ do artigo 195 tem por objetivo "atrair as entidades beneficentes para secundar a ação do Poder Público na efetiva realização dos direitos sociais, sem qualquer intuito lucrativo." (HARADA, 2005, p. 12).

Em relação ao segundo requisito (atender as exigências estabelecidas em lei), o Relator pondera que a definição do alcance formal e material deveria ser considerada sob a ótica do motivo da imunidade em discussão: a garantia de realização de direitos fundamentais sociais, sendo que qualquer interpretação diferente deveria ser evitada, cabendo prestigiar aquela que beneficie a conquista da função política e social própria do $\S 7^{\circ}$ do artigo 195 da Constituição Federal.

Vencido esse tópico o Relator passou a analisar a questão controversa referente a qual espécie legislativa é credenciada pela Constituição Federal para estabelecer as condições necessárias para o gozo ou restrições da imunidade. Novamente o Relator afirmou que para a solução do litígio, o Supremo Tribunal deveria seguir a linha hermenêutica utilizada quanto às outras espécies de imunidade e compreender a cláusula de reserva legal tendo em conta a unidade da Constituição e as funções políticas e sociais próprias da imunidade, portanto deveriam manter a interpretação sistemática e teleológica.

Assim, o Ministro Marco Aurélio afirmou que a interpretação referente às restrições das imunidades tributárias para o sistema constitucional, considerando os valores e princípios que as fundamentam, deveria ser estrita, vedadas conclusões que implicassem negativa à forma e ao conteúdo revelados pela Constituição Federal.

Portanto, continuou o Relator, o constituinte originário ao tratar da limitação ao poder de tributar exigiu no incido II do artigo 146 da Constituição que as exigências legais ao exercício das imunidades são sempre normas de regulação devendo ser dispostas em lei complementar, trazendo a baila que o $\S 7^{\circ}$ do artigo 195 deveria ser interpretado e aplicado em conjunto com o preceito constitucional supracitado, afastando a reserva exclusiva de lei complementar para a disciplina das condições a serem observadas no exercício do direito à imunidade.

Em relação à natureza tributária das contribuições sociais, versou que é no Código Tributário Nacional, artigo 14 que se encontram as condições necessárias para as entidades usufruírem da imunidade, chegando a conclusão que nenhuma lei ordinária de qualquer poder 
tributante pode criar requisitos adicionais, impondo ônus que o constituinte deliberadamente quis afastar. Todos os requisitos acrescentados aos elencados no artigo 14 são inconstitucionais, em face de não possuir o Poder Tributante, nas três esferas, nenhuma força legislativa suplementar, sendo apenas a lei complementar pode impor condições.

Todavia, continua o Relator, o legislador ordinário, sob o pretexto de disciplinar aspectos das entidades pretendentes à imunidade, restringiu o alcance subjetivo da regra constitucional, impondo condições formais reveladoras de autênticos limites à imunidade. Nesse contexto, promoveu a regulação do direito sem que estivesse autorizado pelo artigo 146, inciso II, da Constituição Federal.

Tal limitação seria a necessidade de conceder a imunidade a falsas instituições, sendo que a Constituição autorizou as restrições legais com o claro propósito de assegurar que essas entidades cumpram efetivamente o papel de auxiliar o Estado na prestação de assistência social. Todavia, os requisitos estipulados no artigo14 do Código Tributário Nacional proporcionam o controle de legitimidade dessas entidades a ser implementado e fiscalizado pela Receita Federal do Brasil, sendo possível, nos termos do $\S 1^{\circ}$ do mesmo artigo, a suspensão do benefício caso seja atestada a inobservância dos parâmetros definidos.

Diversamente, os requisitos previstos nos incisos I e II do artigo 55 da Lei $\mathrm{n}^{\circ} 8.212$, de 1991 (BRASIL, 1991), resultaria em grave ofensa à proporcionalidade na perspectiva "vedação de estabelecimento do meio restritivo mais oneroso", uma vez que não implicam controle por órgão competente de fiscalização tributária, capaz de levar à adoção da medida suspensiva, mas estipula condições prévias, impeditivas do exercício da imunidade independente de verificar-se qualquer irregularidade e cuja satisfação depende da atuação de um órgão burocrático denominado Conselho Nacional de Assistência Social.

Nesse contexto, os requisitos constantes no artigo 55, incisos I e II, versados em lei ordinária, não podem ser, conforme o artigo 146, inciso II, da Constituição Federal, constitutivos do direito à imunidade, nem pressupostos anteriores ao exercício deste. Possuem eficácia declaratória, de modo que a negativa de registro implique a verificação dos pressupostos do artigo 14 do Código Tributário Brasileiro pela Receita Federal

Em síntese, o Relator asseverou que:

o artigo 55 da Lei ${ }^{\circ} 8.212$, de 1991, prevê requisitos para o exercício da imunidade tributária, versada no $\S 7^{\circ}$ do artigo 195 da Carta da República, que revelam verdadeiras condições prévias ao aludido direito e, por isso, deve ser reconhecida a inconstitucionalidade formal desse dispositivo no que extrapola o definido no artigo 14 do Código Tributário Nacional, por violação ao artigo 146, inciso II, da Constituição Federal. Os requisitos legais exigidos na parte final do mencionado $\S 7^{\circ}$, enquanto não editada nova lei complementar sobre a matéria, são somente aqueles do aludido artigo 14 do Código. Chego à solução do caso concreto ante a inconstitucionalidade formal do artigo 55 da Lei $\mathrm{n}^{\circ}$ 8.212, de 1991, e a moldura fática delineada no acórdão recorrido (BRASIL, 2017). 
Por fim, o Relator proferiu o voto dando provimento ao recurso, declarando a inconstitucionalidade formal do artigo 55 da Lei $\mathrm{n}^{\circ}$ 8.212, de 1991, restabelecendo o entendimento constante da sentença de $1^{\circ}$ grau e assegurando o direito à imunidade de que trata o artigo 195, $\S 7^{\circ}$, da Constituição Federal de 1988, desconstituindo o crédito tributário inscrito na certidão de dívida ativa.

\section{PROCESSO CONSTITUCIONAL E JURISDIÇÃO NO ESTADO DEMOCRÁTICO DE DIREITO}

O processo constitucional previsto nas diretrizes normativas do Estado Democrático de Direito tem como fundamento de maior importância a garantia da efetiva tutela, proteção e fomento dos direitos fundamentais. Nesse passo, o processo constitucional possui pressupostos essenciais entre os quais se destacam a celeridade processual, a razoável duração do processo, e as formas de controle constitucional (COSTA, 2015, p. 101).

Como ensina Carla Regina Clark da Costa (2015, p. 101), tais pressupostos não se confundem com mitigação ou eliminação de direitos e garantias fundamentais, constitucionalmente instituídos pelos princípios do contraditório, da ampla defesa, do duplo grau de jurisdição, da fundamentação das decisões, do direito à prova, à presença do advogado no curso das demandas, entre outros indispensáveis para a concretização dos pressupostos norteadores do modelo de Estado erigido na Constituição de 1988.

Para Elio Fazzalari (2006, p. 121), é necessário, para identificar o processo que exista uma série de normas (e atos, e posições jurídicas) que se reportem aos destinatários dos efeitos do provimento, realizando um contraditório paritário.

No Estado Democrático de Direito, não se deve deixar a cargo do juiz a busca pela verdade real, mas deve-se, sim, deixar que as partes, mediante o devido processo constitucional, estruturem aquela que será a verdade construída no processo, tornando-se marco para a fundamentação do provimento estatal construído democraticamente (VEZZOSI, 2010, p. 44).

Na lição de Felippe Borring Rocha (2014, p. 171-172), o contraditório é um dos institutos mais respeitável à ciência processual, uma vez que vai além de um qualificador do processo judicial, representando um dos mais importantes componentes lógico-filosófico e estrutural do desenvolvimento legítimo da relação jurídica processual, sendo o corolário do devido processo legal e densificador de garantias fundamentais, dentre as quais se destaca o princípio democrático.

Não se pode negar o importante papel desempenhado pela garantia do contraditório, que representa o desenvolvimento válido do processo, que visa atribuir legitimidade à formação do convencimento do juiz, através da oitiva das partes processuais. Trata-se de uma garantia deferida a todos aqueles que atuam de forma parcial no processo, submetidos ou não aos efeitos da coisa julgada (DIDIER JÚNIOR. 2015, p. 51).

O contraditório formal se traduz no direito da parte apresentar suas razões no processo, o que evidentemente supõe o direito a ser cientificada de sua existência para que possa fazê-lo (BAHIA; VECCHIATTI, 2012, p. 926). 
Pode-se afirmar que na tramitação do recurso extraordinário representativo da controvérsia $\mathrm{n}^{\circ} 566.622$, foi garantido às partes a participação no processo por meio do contraditório formal, visto que foram previamente cientificadas do processo e dele participaram apresentando, tempestivamente, suas razões e contrarrazões.

Não se pode negar que o contraditório formal tem sido atualmente garantido nos processos. Por outro lado, de nada adianta apresentar suas razões no processo se elas forem singelamente ignoradas ou desconsideradas pela autoridade julgadora. Afinal, quando a parte ou o terceiro apresentam suas razões, tem a legítima expectativa e pretensão a que elas sejam efetivamente consideradas e enfrentadas pelo órgão julgador (BAHIA; VECCHIATTI, 2012, p. 926).

Percebe-se que as teses e alegações das partes envolvidas no recurso extraordinário representativo da controvérsia $n^{\circ} 566.622$, foram consideradas e analisadas no voto do relator do recurso no Supremo Tribunal Federal, Ministro Marco Aurélio, demonstrando que o contraditório material ou substantivo foi garantido nessa decisão.

A utilidade do contraditório não pode encerrar a ideia de dizer e contradizer apenas, mas sim, efetivamente, influenciar a formação da decisão e à garantia da não surpresa na decisão judicial que advier. Para tanto, torna-se imprescindível o expresso enfrentamento das razões apresentadas no processo. Nesse sentido, tem-se falado em contraditório substantivo (contraditório material), em contraposição ao contraditório meramente formal (BAHIA; VECCHIATTI, 2012, p. 928).

Assim como no julgamento do recurso extraordinário representativo da controvérsia $\mathrm{n}^{\circ}$ 566.622, o contraditório deve garantir o diálogo completo e íntegro entre as partes e o juiz, possibilitando que todas as alegações levadas a juízo e vinculadas ao mérito da causa sejam avaliadas, confrontadas e solucionadas pelo julgador no conjunto do processo decisório (ROCHA, 2014, p. 178).

No mesmo sentido Antônio do Passo Cabral (2014, p. 215) reafirma a ideia de que o contraditório contemporâneo não se coaduna mais com a postura autoritária de ignorar a argumentação dos litigantes, para o escritor o juiz deve sim enfrentar os argumentos das partes na sentença, mesmo que não os use para chegar às suas conclusões para o litígio, sob pena de a decisão não ser considerada como possuidora de um debate adequado e efetivo.

\section{A PARTICIPAÇÃO DO AMICUS CURIAE NO JULGAMENTO DO RECURSO EXTRAORDINÁRIO REPRESENTATIVO DA CONTROVÉRSIA No ${ }^{\circ} 66.622$}

A expressão amicus curiae tem sua origem no latim, significando, em língua portuguesa, "amigo da corte", ou seja, aquele que colabora com o órgão jurisdicional na solução de um caso, fornecendo-lhe informações úteis, bem como apresentando um novo enfoque para a matéria. (FARIAS, 2013, p. 83).

Se por um lado é certa a origem da expressão amicus curiae, o mesmo não se pode dizer sobre a origem do instituto. O que se pode afirmar é o fato de que foi nos Estados Unidos, durante o século o XIX, que o instituto começou a ganhar a forma que hoje se conhece, tendo a 
jurisprudência da Suprema Corte norte-americana um papel relevante na sistematização dessa figura processual (FARIAS, 2013, p. 83-84).

O instituto do amicus curiae, no direito brasileiro, teve aparição mais recente, de modo que ainda se encontra em estágio de evolução. Segundo o autor Luciano Andrade Farias (2013, p. 84), é usual apontar a previsão contida no artigo 31 da Lei $n^{\circ} 6.385 / 76$, que dispõe sobre o Mercado de Valores Mobiliários, criando a Comissão de Valores Mobiliários - CVM, como a primeira previsão legal de atuação do amicus curiae na legislação pátria.

A participação do amicus curiae no âmbito do Supremo Tribunal Federal está regulada na Lei $n^{\circ}$ 9.868/99 (BRASIL, 1999a) que dispõe sobre o processo e julgamento da Ação Direta de Inconstitucionalidade e da Ação declaratória de Constitucionalidade, e na Lei $\mathrm{n}^{\circ}$ 9.882/99 (BRASIL, 1999b) que dispõe sobre o processo e julgamento da Arguição de Descumprimento de Preceito Fundamental, e ainda, em seu Regimento Interno.

A evolução social a cada dia torna mais complexa as relações jurídicas postas à apreciação do Poder Judiciário, neste contexto, os julgadores, por mais preparados que estejam, não terão à disposição todo o conhecimento necessário para proferir a decisão mais adequada. Nesse sentido, a participação da sociedade civil, por meio do instituto do amicus curiae, surge como um meio de aperfeiçoamento do exercício da função jurisdicional (FARIAS, 2013, p. 99).

Diferente da atuação do assistente que, em via de regra, está na relação jurídica em prol de um indivíduo, o amicus curiae atua em prol de um interesse, que pode, até mesmo, não ser titularizado por ninguém, embora seja compartilhado difusa ou coletivamente por um grupo de pessoas. Esse interesse, contudo, tende a ser afetado pelo que vier a ser decidido no processo (BUENO, 2012, p. 1023).

A finalidade do ingresso do amicus curiae é aprimorar a decisão jurisdicional a ser proferida, levando ao Estado-juiz informações complementares que provavelmente não é de seu conhecimento, podendo desempenhar todo e qualquer ato processual que seja correlato para atingir sua finalidade (BUENO, 2012, p. 1024).

No julgamento do recurso extraordinário representativo da controvérsia $n .^{\circ} 566.622$, foram admitidos na qualidade de amicus curiae a Confederação Nacional dos Estabelecimentos de Ensino - COFENEN e o Conselho Federal da Ordem dos Advogados do Brasil - CFOAB.

$\mathrm{O}$ amicus curiae deve ser o interlocutor entre os Tribunais e a sociedade civil, representado a diversidade de atores que existem dispersos na sociedade, canalizando a pluralidade de vozes nela existente, representando-os adequadamente. Por outro lado, o amicus curiae é também canal de representação dos próprios interesses do Estado que precisam ser levados em conta pelos variados órgãos jurisdicionais para bem julgar os processos que lhe são submetidos (BUENO, 2012, p. 1047).

Na prática, entretanto, tem se discutido se a ampliação da participação do amicus curiae no Tribunal é de fato uma medida que impacta positivamente na qualidade das decisões. (ALMEIDA, 2012, p. 1096). Como se verificou no julgamento do recurso extraordinário representativo da controvérsia ${ }^{\circ} 566.622$, a participação do amicus curiae no processo, bem como a realização de 
audiências públicas não interferiram na prolação dos votos dos ministros do Supremo Tribunal Federal. Em nenhum momento o relator do recurso, Ministro Marco Aurélio, bem como os demais ministros, fizeram menção às teses defendidas pelas instituições aceitas na figura do amicus curiae.

Neste contexto, de nada adiantará a admissão de diversas entidades ou pessoas como amicus curiae em um processo se os seus argumentos forem desconsiderados pela decisão respectiva. Não basta admitir o amicus curiae e permitir a sua manifestação escrita e a sua sustentação oral, é preciso que o Tribunal enfrente as razoes por ele apresentadas, seja para com elas concordar, seja para rejeitá-las (BAHIA; VECCHIATTI, 2012, p. 937-938).

Uma das preocupações dos Tribunais é que não seja admitida a participação de diversos amicus curiae, sob o fundamento de não tumultuar o processo, postergando o provimento final da prestação jurisdicional. Buscando evitar tais situações o Regimento Interno do Supremo Tribunal Federal, em seu artigo 21, XVIII, define como competência do relator, decidir, de forma irrecorrível, sobre a manifestação de terceiros, subscrita por procurador habilitado, em audiências públicas ou nos processos de sua relatoria.

Entretanto, caso seja admitida a participação de diversos amicus curiae, para que o processo não fique tumultuado, o enfretamento das argumentações poderia ser realizado em bloco, como por exemplo, se diversas partes invocarem o princípio da igualdade com a mesma linha argumentativa, bastaria o enfrentamento do tema. O que não se pode admitir é que o Tribunal decida de uma forma ou de outra sem enfrentar as teses e argumentações defendidas pelas partes, o mesmo valendo para os argumentos apresentados pelo amicus curiae. (BAHIA; VECCHIATTI, 2012, p. 937-938)

O que não se pode negar é o fato de a sociedade ter descoberto na figura do amicus curiae uma maneira de participar e compartilhar das decisões do Tribunal. É importante que o Tribunal reconheça esta demanda e possa ampliar as hipóteses de admissibilidade e das capacidades processuais, bem como a incorporação destes argumentos em suas deliberações, o que certamente terá o condão de pluralizar o debate e democratizar os processos (ALMEIDA, 2012, p. 1096).

\section{CONSIDERAÇÕES FINAIS}

O cenário jurídico atual tem sofrido constantes modificações para se aprimorar dentro do conceito de processo constitucional e jurisdição no Estado Democrático de Direito. Vários institutos jurídicos estão sofrendo transformações em seus conceitos, modificando sua forma de aplicação para se adequarem dentro das concepções de processo participativo.

Neste cenário, pode se concluir que na tramitação do recurso extraordinário representativo da controvérsia $n^{\circ} 566.622$, foi garantido às partes a participação no processo por meio do contraditório tanto formal como material, visto que foram previamente cientificadas do processo e dele participaram apresentando, suas razões e contrarrazões, bem como tiveram suas teses e alegações consideradas e analisadas no voto do relator do recurso no Supremo Tribunal Federal.

Constatou-se a participação, no julgamento do recurso extraordinário representativo da 
controvérsia $n^{\circ}$ 566.622, das entidades Confederação Nacional dos Estabelecimentos de Ensino - COFENEN e o Conselho Federal da Ordem dos Advogados do Brasil - CFOAB, na qualidade de amicus curiae. Entretanto, a admissão não corroborou para a que o acordão proferido fosse considerado uma decisão participativa, visto que a admissão do amicus curiae no processo, bem como a realização de audiências públicas não interferiram na prolação dos votos dos ministros do Supremo Tribunal Federal. Como mencionando ao longo do estudo, em nenhum momento o relator do recurso, Ministro Marco Aurélio, bem como os demais ministros, fizeram menção às teses defendidas pelas instituições aceitas na figura do amicus curiae.

Por fim, pode-se concluir que é necessária uma maior conscientização por parte dos Ministros ao decidir sobre matérias de relevância geral, ouvindo as partes e intervenientes, para que a decisão seja construída de forma participativa levando em consideração e enfrentado a tese apontada.

\section{REFERÊNCIAS}

ALMEIDA, Eloísa Machado. O amicus curiae na jurisprudência do Supremo Tribunal Federal. Revista Brasileira de Estudos Constitucionais, Goiânia, ano 6, n. 24, p. 1053-1098, out./dez. 2012.

ÁVILA, Humberto. Sistema constitucional tributário. 5. ed. São Paulo: Saraiva, 2012.

BAHIA, Alexandre Melo Franco; VECCHIATTI, Paulo Roberto Lotti. O respeito ao direito fundamental ao contraditório substantivo como condição necessária para que se leve a sério o instituto do amicus curiae. Revista Brasileira de Estudos Constitucionais, Goiânia, ano 6, n. 24, p. 913-941, out./dez. 2012.

BARRETO, Aires Fernandino. Imunidades tributárias: limitações constitucionais ao poder de tributar. 2. ed. São Paulo: Dialética, 2001.

BORGES, José Souto Maior. Teoria geral da isenção tributária. 3. ed. São Paulo: Malheiros, 2011.

BRASIL. Constituição Federal de 1988. Brasília, DF: Presidência da República, 1988.

Disponível em: http://www.planalto.gov.br/ccivil_03/constituicao/constituicao.htm. Acesso em: 24 maio 2019.

BRASIL. Lei no 8.212, de 24 de julho de 1991. Dispõe sobre a organização da Seguridade Social, institui Plano de Custeio, e dá outras providências. Brasília, DF: Presidência da República, 1991. Disponível em: http://www.planalto.gov.br/ccivil_03/leis/L8212cons.htm. Acesso em: 24 maio 2019.

BRASIL. Lei $\mathbf{n}^{0}$ 9.868, de 10 de novembro de 1999. Dispõe sobre o processo e julgamento da ação direta de inconstitucionalidade e da ação declaratória de constitucionalidade perante o Supremo Tribunal Federal. Brasília, DF: Presidência da República, 1999a. Disponível em: http:// www.planalto.gov.br/ccivil_03/Leis/L9868.htm. Acesso em: 24 maio 2019. 
BRASIL. Lei $\mathbf{n}^{0}$ 9.882, de 03 de dezembro de 1999. Dispõe sobre o processo e julgamento da arguição de descumprimento de preceito fundamental, nos termos do $\S 1^{\circ}$ do artigo 102 da Constituição Federal. Brasília, DF: Presidência da República, 1999b. Disponível em: http://www. planalto.gov.br/ccivil_03/LEIS/L9882.htm. Acesso em: 24 maio 2019.

BRASIL. Supremo Tribunal Federal. Recurso Extraordinário 237.718/SP. Relator: Ministro Sepúlveda Pertence, 29 de março de 2001. Disponível em: http://portal.stf.jus.br/processos/ detalhe.asp?incidente=1731220. Acesso em: 25 abr. 2019

BRASIL. Supremo Tribunal Federal. Recurso Extraordinário 566.622/RS. Relator: Ministro Marco Aurélio, 23 de fevereiro de 2017. Disponível em: http://portal.stf.jus.br/processos/detalhe. asp?incidente $=2565291$. Acesso em: 25 abr. 2019.

BRASIL. Supremo Tribunal Federal. Regimento interno. Brasília: STF; Secretaria de Altos Estudos, Pesquisas e Gestão da Informação, 2020. Disponível em: http:/www.stf.jus.br/arquivo/ cms/legislacaoRegimentoInterno/anexo/RISTF.pdf. Acesso em: 25 abr. 2019.

BUENO, Cássio Scarpinella. Amicus curiae e audiência públicas na jurisdição constitucional Reflexões de um processualista civil. Revista Brasileira de Estudos Constitucionais, Goiânia, ano 6, n. 24, p. 1021-1051, out./dez. 2012.

CABRAL, Antônio do Passo. A escolha da causa-piloto nos Incidentes de Resolução de Processos Repetitivos. Revista de Processo, São Paulo, v. 23, p. 201-223, maio 2014.

COSTA, Carla Regina Clark da. O processo constitucional como garantida da efetiva tutela, proteção e fomento dos direitos fundamentais. In: CASTRO, João Antônio Lima (org.). Direito processual e a era digital. Belo Horizonte: PUC Minas, Instituto de Educação Continuada, 2015.

DIDIER JÚNIOR. Freddie. Curso de direito processual civil: teoria geral do processo e processo de conhecimento. 17. ed. Salvador: Editora Jus PODIVM, 2015. v. 1.

FARIAS, Luciano Andrade. A atuação do amicus curiae na jurisdição constitucional brasileira. Escola da AGU, Brasília, v. 2, p. 81-100, jun. 2013.

FAZZALARI, Elio. Instituições de direito processual. Campinas: Bookseller, 2006.

GONÇALVES, Aroldo Plínio. Técnica processual e teoria do processo. Rio de Janeiro: Aide, 1992.

HARADA, Kioshi. Imunidade das entidades de assistência social. requisitos legais para sua fruição. Revista Nacional de Direito e Jurisprudência, Ribeirão Preto, Ano 6, n. 66, jun. 2005.

LAKATOS, Eva Maria; MARCONI, Marina de Andrade. Fundamentos de metodologia científica. 5. ed. São Paulo: Atlas, 2003.

MARINS, James. Imunidade Tributária das Instituições de Educação e Assistência Social. In: ROCHA, Valdir de Oliveira (coord.). Grandes questões atuais do direito tributário. São Paulo: Dialética, 1999. v. III. 
ROCHA, Felippe Borring. O contraditório utilitarista. Revista de Processo, São Paulo, ano 39, n. 229, p. 172-197, mar. 2014.

SOUZA NETO, Cláudio Pereira de; SARMENTO, Daniel. Direito constitucional: teoria, história e métodos de trabalho. Belo Horizonte: Fórum, 2012.

VEZZOSI, Rafael Geraldo Magalhães. A verdade estruturada no processo civil do estado democrático de direito. In: CASTRO, João Antônio Lima (coord.). Coletânea direito processual: estudos jurídicos aplicados. Belo Horizonte: PUC Minas, 2010. p. 32-46.

Como Como citar: GONZAGA, André dos Santos; BRASIL, Deilton Ribeiro. A fundamentação da decisão e as garantias do contraditório no julgamento do Recurso Extraordinário representativo da controvérsia $n^{\circ}$ 566.622. Revista do Direito Público, Londrina, v. 16, n. 1, p. 171-185, abr. 2021. DOI: 10.5433/24157-108104-1.2021v16n1p. 171. ISSN: 1980-511X

Recebido em: 28/09/2019

Aprovado em: 14/02/2020 